\title{
Democracy, the Open Society and Truth
}

\author{
Jan-Erik Lane \\ University of Geneva, Geneva, Switzerland \\ Email: janeklane@gmail.com
}

How to cite this paper: Lane, J.-E. (2020) Democracy, the Open Society and Truth. Open Journal of Philosophy, 10, 129-136. https://doi.org/10.4236/ojpp.2020.101009

Received: December 19, 2019

Accepted: February 8, 2020

Published: February 11, 2020

Copyright (c) 2020 by author(s) and Scientific Research Publishing Inc. This work is licensed under the Creative Commons Attribution International License (CC BY 4.0).

http://creativecommons.org/licenses/by/4.0/

\begin{abstract}
Karl Popper discovered the link between the open society and scientific discovery with the help of his analysis of growth of scientific theories (Popper, $1945,1959)$. Only in an open society can hypotheses or models be falsified. His principle of falsification applies not only to scientific argument but also to social science beliefs and political propaganda. Thus, democracy nourishes an open society seeking the truth. Actually, democracy is the sole political regime that promotes the truth in an open society. The rationale for democracy is to be found in game theory, in particular the principal agent framework in the economics of information.
\end{abstract}

\section{Keywords}

Political Regime, Information, Open Society, Scientific Discovery, Knowledge Growth, Popper, Principal Agent

\section{Introduction}

Looking for democracy in the history of political philosophy or theory, one is bound to be somewhat disappointed. No major democratic theory was propounded until 1762 when J.J. Rousseau's Social Contract (Rousseau, 1962) appeared. It clearly suggested a revolutionary concept of the people, but Rousseau's theory of democracy was arguably romantic, based on the dangerous notion that the people are always right, as well as that a majority could force a minority to be "free". Thus, popular sovereignty was identical with justice.

In the philosophy of the Ancient Period, one encounters little appreciation for democracy, with the exception of a few Cynics. The Greek and Roman empires were slave-based civilizations with roughly half of the population in captivity. Buying and selling human labour was the commodity that drove the expansion of regimes and military adventures. When trading slaves was no longer profitable, the Middle Ages transformed slavery into serfdom. Free peasants survived in 
Western Europe and were divided between promoting democracy with the Workers Movement or supported dictatorship as in the case of Germany. The ultimate outcome was the victory of democracy over dictatorship in WWII. The end of the war saw the emergence of major books in democratic theory by Dane Alf Ross (1952), Swede Herbert Tingsten (1965), Norwegian Arne Naess (1956) and Stein Rokkan as well as American Anthony Downs (1957). Nevertheless, there remained a doubt in the literature on the viability of the democratic regime.

\section{Democracy in the History of Ideas}

Ordinary men and women do not appear in political theory until the coming of the democratic regime in the 20th century. Aristote argued that democracy entails the risk of mob rule turning into tyranny. Stoicism and Epicureans did not favour democracy. And the union of Christianity with Stoicism in late Antiquity may have made slavery unethical, but in medieval Europe, hierarchy prevailed in both Church and State.

When Grotius (2012) secularist political thought, he spoke about natural law rights and never democratic right. In fact, this was Stoicism modernised. The modernisation of Epicurism came with Hobbes (1651) and Spinoza (2000), starting from the axiom of universal selfishness and rational self-aggrandisement instead of Grotius eternal rules:

1) Do not lie;

2) Do not steal;

3) Do not hurt anyone;

4) On damage pay compensation.

Hobbes (1651) and Spinoza (2000) found no such duties but only rational selfperservation. Modern post-stoics found such rules in Right Reason (Rawls, 19671; Dworkin, 2002), but was there no role to play for the demo? Post-Epicureans looked elsewhere, namely in the authority of the state. Thus, Hobbes (1651) envisaged an authoritarian government with many control over people. However, Spinoza (2000) was sceptical about monarchy and could accept democracy, fearing that one-man rule would make total selfinterest on his part possible. Hitler not only sent millions of German youth into gruesome death for his ideosyncratic objectives (Beevor, 1999; Clark, 1985), but also became quite wealthy "selling" his only book to schools and enterprises.

Spinoza died before finishing his Political Treatise, although he argued that political choice involved weighing the pros and cons of monarchy, oligarchy and democracy. Locke following Stoicism claimed that rights were inborn and could not be alienated, but he placed the plebicite with the wealthy. Constitutional monarchy with restricted plebiscite was also recommended by Kant (1996). He took interestingly his definition of the concept of social justice from the great Romania lawyers:

1) Speak the truth; 
2) Live a decent life;

3) Give to each one his or her "due".

However, he never told us what is due to is: food, freedom, equality, environment, culture, etc.

Rousseau (1962) presented a contract theory of democracy moving from a Hobbesian predicament of epicurean egoism to the romantic unity of the people always acting Right, populist democracy. He originated the theory of totalitarian democracy (Talmon, 1976); where people can be forced to be free.

Arguments over the nature of the democratic regime played a major role in the Arbeiterbewegung, as Social Democrazy and Communism took different stances to the idea of a dictatorship of the proletariat. When Communist regimes were established after WW2 they were claimed to be "true" democratic polities. Lenin put the Tjeka in place already in 1918 to get rid of opponents, called "enemies" of something.

In any case, the real-life democracy won the Great War and numerous countries turned to the democratic regime including Latin America. But its legitimation remained undecided in front of new ideologies. Swedish political scientist Herbert Tingsten (1933) published early 1933 a penetrative analysis of "Victory of Democrácy and its Crisis" that looked at why the democratic regime may not persist.

\section{Dahl's Distinction}

Thus, the world's most well-known expert on democracy, Robert Dahl, hesitated to name any country a "democracy". Instead, he argued that some 50 countries were a "polyarchy", i.e. an unaccomplished democracy (Dahl, 1971). He rejected the hypothesis that democracy leads to mob rule, but he still feared that the role of the people would not be decisive on all issues at any time. Dahl's distinction between democracy/constitutional democracy (polyarchy) on the one hand and ideal type democracy (the rule of the people) on the other side is not clarifying. One must point out that in any political order there will be principal agent relationships, because the demos have to hire agents in order to get the job of the Government carried out: policy making and policy implementation.

In roughly half of the world's countries, there are democratic regimes operating in an open society. These nations are characterized by free speech, rule of law, free and fair elections, political competition and a dominant role of higher education in information. They are also market economies, with decentralized information. Here we have Poppers idea of falsification as the driving force. Any attempt to hide, control or eliminate the truth will be crushed by the spontaneous order of an open society.

Democracy is the political regime of an open society. At the end of the day, the voters show their agents information on what policies they wish to be implemented. The secrecy of the success of democracy lies in principal agent relationships, as the electorate selects three kinds of agents with countervailing power; 
executive, legislative and judicial agents.

The term democracy has a positive evaluation in the sense that it has spread widely (Naess, 1956). I agree with Ross (1952) and Tingsten (1965) that democracy is majority rule and not related to economic democracy, real equality or democratic society. Democracy is politics in an open society with an unlimited quest for the truth. Any statement, judgment or policy can in principle be falsified by new knowledge. If something is so bad that it must be hidden, it must not be true. The core of democracy is uncontrolled information. Often democracy is advocated as the realization of the preferences of the people but if the people are divided democracy picks the majority winner as the principle of the polity. The foremost genius of political philosophy is Marquis de Montesquieu from Bordeaux.

One may separate between two kinds of undemocratic political regimes. While both have a flawed principal agent relationship, in the first authoritarian type, political agents rule beyond the control of the people, fusing legislative power. In the second genre of totalitarian regimes, the political leader and his/her clique reverse the principal agent relationships, subjugating to serve as an instrument of their own power.

\section{Information}

Information is the glue of society, connecting the individuals together. When information is systematically false, the entire society degenerates. The superiority of democracy lies neither in high participation nor communication, rather in the impossibility of hiding errors and spreading lies.

1) Authoritarian Regimes: Their essence is to suppress information and deny truth by incarcerating citizens, e.g. Franco (Spain), Latin American dictatorships.

2) Totalitarian Regimes: Essence is to replace truth with myths by means of propaganda. From 1933 Germany was transformed from a cultured nation into the inculcation of lies, in particular about human nature. The war effort was also untruthful. Thus, the attack on the Soviet Union was ludicrously named "operation Barbarossa" after a feudal king. When the Third Reich had been defeated by the Britons in the skies over England, another war had to be instigated. They chose the Soviet Union in spite of the Molotov Ribbentrop treaty, sending millions of young countrymen to gruesome deaths. It was referred to as "Blitzkrieg", but they had to march with 700,000 horses. The propaganda boosted that this was a modern war fought with tanks, but Germany only had 3000 of them whereas the Red Army disposed of them in much higher numbers, most prominently the outstanding T-34. Reichsführer Adolf Hitler was the supreme commander of the Wehrmacht, but he had no military education, merely a corporal from World War I who ended up in a mental asylum. He played around with his renowned generals, moving divisions up and down and back and forth on a map. Criticism was met by violent outbursts and anger. No person in German history 
has ever misled the people to such an extent in a closed society. The political myth recurred in Italian and Japanese authoritarianism. How many Italian families lost a son or a father in the wars in Northern Africa, falsely inspired by the Roman Empire? The atrocities committed by Japan's Armed Forces in the Pacific were inspired by false information.

3) Democratic Regimes: Essence is the revelation of falsehood and the unstoppable search for the truth by independent agents. In a democracy, political propaganda runs aground due to criticism, falsification and refutation in an open society.

\section{A Contemporary Montesquieu System}

Many well-ordered societies of present times adhere to the basics of the Montesquieu (1989) model. In the context of the principal agent framework, these rule of law countries employ three kinds of political agents and they offer mechanisms for the principal to control them. The outcome is that true information will always be forthcoming sooner or later in an open society. By checking each other, nobody can assume total power or misuse false information. Civil society and mass media further contribute to the system of checks and balances, a legacy of the ingenuity of French philosopher Montesquieu (1989).

1) Judicial Agents

In general, the principal would welcome judicial integrity and the option to test public decision-making before the judiciary. More contested is the structure of legal review. Is it at all necessary for democratic decision-making?

Enquiries into policy implementation by national government bureaux, agencies, boards or regional and local authorities are essential for reducing the information advantage of politicians and political parties. These enquiries may be recurring or special ones. The structure of judicial overview varies much from ordinary courts to special tribunals. Some countries have administrative court as well as the Ombudsman — the Swedish, Danish or Swiss type.

The position of the single individual is much better when the practice of public administration can be challenged in some court somehow. The possibility of appeal has an enormous impact, especially on anticipations or expectations on the bureaucracy. The Scandinavian contribution to constitutionalism-OMBUDSMANis important for ordinary citizens.

Judicial enquiries can be done in several shapes, where for instance judges collaborate with legislators or experts from public administration.

2) Legislative Agents

Politicians in the legislature' or groups of them like parties-have a strong wish to get re-elected for various reasons like position, income, prestige or good work. At elections, one expects that falsity occurs as lying or exaggerations could pay off.

Peltzman (1980) models the strategy of rational politicians to present a policy mix maximizing the probability of electoral victory.

In order to reduce their information gap in relation to the executive and pub- 
lic administration, the legislature engages in oversight of public programs and the use of public money. A variety of oversight committees and boards are available for legislatures to make enquiries into program performance, both legality and efficiency. Not only the US and other presidential systems but also parliamentary regimes-a truly large institutional variation, have procedures for disclosure of executive malpractice.

To be a legislator earns you prestige and, in several countries, good money, as in the EU Parliament. The American system with PACS (political action committees) leads to huge budgets for legislators seeking election or re-election. However, legislative oversight is hampered by the influence of organized interests, lobbying both policymaking and policy implementation-the capture theory.

\section{3) Executive Agents}

The executive has a range of agencies at its command. Can they be trusted? As responsible for the performance in almost all public programs the executive depends upon the flow of information. How can the executive control for asymmetrical information - the basic incentives problematic in public administration?

The amount of resources controlled by the executive as well as the bureaucracy and public enterprise sector under its wings is normally overwhelming. The public sector comprises public resource allocation and transfers payment, making up between 20 - 55 percent of GDP, depending on the political-economy regime of the country. How are these resources to be used, ideally as well as employed reality?

\section{Information}

Information about politically relevant events and circumstances is much sought after. The mass media turns it out all day long. Political agents strive to be the first to know but also the population often follows the stream of research on a daily basis. Montesquieu's (1989) separation of powers entails stating that there are three kinds of expertise-executive, legislative and judicial—and they are to be separated on a personal level.

Access to information as well as control of information is central in day-to-day political competition. New information alters the behaviour in principal-agent interactions. The dynamics of politics and policy are to a large degree influenced or even shaped by the flow of new information. The arrival of new domestic or international news may have a profound impact on the principal and the political agents: government and its bureaucracy, the legislative and the judiciary. In the search for correct information, the principal may draw upon the separation of powers to reduce the asymmetric information advantage of agents, for instance by one agent engaging in oversight of another agent.

A penetrative attempt to derive a rational and just public sector for an advanced economy was made in the so-called public finance approach. The lessons of this exercise were also relevant for Third World countries. Ubsing criteria on 
rationality in resource allocation as well as some criterion on justice in social security the public sector would remove market failures of various kinds.

The successful public finance models were to be found in the analysis essays of efficiency, micro or macro. But the concept of income and wealth redistribution towards more of social justice proved very contested among social scientists and economists as well as philosophers. How much and in what forms?

Consider, please, the difference between ultra liberal Nozick (1974)—no redistribution-and socialist Barry (1995)—equalise until impartiality. In any case the book by Musgrave and Musgrave (1973) is still instructive-Public Finance in Theory and Practice.

The difference between constitutional democracy and other regimes is merely the comprehensive occurrence of these selfish tactics as well as the systematic absence of corrections and disclosure. The people as the ultimate principal of the polity can only be vigilant as electorate as well as instruct legislative and judicial agents to check and balance the executive and public administration. At the end of the line, the firing option must be employed.

The quality of the public sector can only be protected by countervailing powers. Countries that are ill-fated drown in government mismanagement. A country where an elite rule unhindered allows the capture of a huge rent for politicians. The market economy adds to the openness of society, but a mixed economy is preferable over pure capitalism. In a mixed economy, public expenditures promote real equality. Especially redistribution in kind is important for the equalization of life opportunities, which as a matter of fact socialist Piketty fails to underline (Piketty, 2019).

\section{Conclusion}

Philosophy of science has emerged after WWII as a complex theory of the growth of knowledge, informing us about two possible kinds of growth processes: incremental and non-incremental growth, respectively. To the former belongs the slow cumulative process of minor refinements and new applications of existing theories. The latter is connected to the scientific revolutions when a major new theory or breakthrough in data processing is presented. A sustained process of growth of knowledge is only possible in an open society with a democratic regime. The search for truth in Natural Sciences, Arts and Social Sciences can only flourish in the presence of institutions of democracy and an open society. The so-called "Western World" is the home of this triad of entities: democratic political regimes, open society and free universities. Their existence should not be taken for granted, instead, its ethos ought to be spread to the Moslem civilization as well as to the Far East.

\section{Conflicts of Interest}

The authors declare no conflicts of interest regarding the publication of this paper. 


\section{References}

Barry, B. (1995). Justice as Impartiality. Oxford, United Kingdom: Clarendon Press.

Beevor, A. (1999). Stalingrad. London, United Kingdom: Penguin Books.

Clark, A. (1985). Barbarossa: The Russian-German Conflict, 1941-45. New York: HarperCollins Publishers.

Dahl, R. (1971). Polyarchy: Participation and Opposition. New Haven, CT: Yale University Press.

Downs, A. (1957). An Economic Theory of Democracy. New York: Harper.

Dworkin, R. (2002). Sovereign Virtue. Cambridge, MA: Harvard University Press. https://doi.org/10.1086/341579

Grotius, H. (2012). On the Law of War and Peace. Cambridge, UK: Cambridge University Press.

Hobbes, T. (1651). Leviathan. London, England.

Kant, I. (1996). The Metaphysics of Morals. Cambridge, UK: Cambridge University Press. https://doi.org/10.1017/CBO9780511809644

Montesquieu (1989). Montesquieu: The Spirit of the Laws. Cambridge, UK: Cambridge University Press.

Musgrave, R., \& Musgrave, P. (1973). Public Finance in Theory and Practice. New York: McGraw-Hill.

Naess, A. (1956). Democracy, Ideology and Objectivity. Studies in the Semantics andCognitive Analysis of Ideological Controversy. Oslo, Norway: Norwegian Research Council for Science and the Humanities.

Nozick, R. (1974). Anarchy, State and Utopia. New York: Basic Books.

Peltzman, S. (1980). The Growth of Government. Journal of Law and Economics, 23, 209-287. https://doi.org/10.1086/466962

Piketty, T. (2019). Capital and Ideology. Cambridge, MA: Harvard University Press.

Popper, K. (1945). The Open Society and Its Enemies. Abingdon-on-Thames, United Kingdom: Routledge.

Popper, K. (1959). The Logic of Scientific Discovery. Abingdon-on-Thames, United Kingdom: Routledge. https://doi.org/10.1063/1.3060577

Rawls, J. (1971). A Theory of Justice. Cambridge, MA: Harvard University Press.

Ross, A. (1952). Why Democracy? Cambridge, MA: Harvard University Press. https://doi.org/10.4159/harvard.9780674433557

Rousseau, J. J. (1762). The Social Contract. Paris, France.

Spinoza, B. (2000). Political Treatise. Cambridge, MA: Hackett Publishing Co.

Talmon, J. L. (1976). The Origins of Totalitarian Democracy. London, United Kingdom: Secker \& Warburg

Tingsten, H. (1933). Demokratins Seger och Kris. Stockholm: Bonniers.

Tingsten, H. (1965). The Problem of Democracy. New York: Bedminster Press. 